Pobrane z czasopisma Annales H - Oeconomia http://oeconomia.annales.umcs.pl Data: 26/04/2023 12:53:37

DOI:10.17951/h.2017.51.2.105

\begin{tabular}{lcl}
\hline \multicolumn{2}{c}{ A N N A L E S } \\
UNIVERSITATIS MARIAE CURIE-SKŁODOWSKA \\
LUBLIN - POLONIA \\
VOL.LI, 2 & SECTIOH \\
\hline
\end{tabular}

University of Economics in Katowice

MICHAŁ JAŚNIOK

jasniok@interia.pl

KRYSTYNA ŚLIWIŃSKA

krystyna.sliwinska@wp.pl

\title{
Strategic Marketing of Political Entity in Market Virtualization Context
}

Strategiczne zarządzanie podmiotem politycznym w kontekście wirtualizacji rynku

Key words: strategy; management; politics; virtualization; cyberdemocracy

Slowa kluczowe: strategia; zarządzanie; polityka; wirtualizacja; cyberdemokracja

JEL codes: M31; D72; D73

\section{Introduction}

The change is a constant feature of the political market. Nowadays, the political parties are obliged to take part in a competition in new conditions that they are not yet fully prepared to. The framework to understand new structure of political market starts with the comparison of the markets evolution and develops via different stages into a model for cyberdemocracy and networks [Goede 2010]. Although the evolution of processes in politics is slower than those occurring on the commercial markets, they have been proceeding in a similar path so far. The marketing strategies of political entities finally started to be directed to the particular market segments, instead to mass receiver. Nowadays, parties - similarly to enterprises - are consolidating and undergoing the processes of international integration. By the year 2010, there was only one political brand on the political market with a European range 
(Libertas). However, in the near future, the parties that are taking part in the process of integration will consolidate and will be subjected to integration processes.

To study a new market reality is needed to structure conceptual framework complexity. A conceptual framework is an intermediate theory that connects aspects of the research and so it provides logic, order and consistency between the different elements. The presented information, based on extensive literature research and qualitative research (prediction) could expand the knowledge about the planning of marketing activities of the parties.

\section{Theoretical background}

\subsection{Cyberdemocracy as a new evolutional stage of the political market}

Some authors believe that the political marketing has fundamentally changed the model of political systems [e.g. Tapscott and Williams 2010]. Democracy is a normative dynamically evolving project and has to be shaped for and by citizens. But, in fact, new expectations of the receivers, new processes of information exchange, new possibilities of meeting the needs (e.g. online shopping and e-voting) change structure of the market, leading us towards the new regime type called cyberdemocracy [Ferber et al. 2003]. It was known by various names, including "digital democracy" and "e-democracy". One-sided media communication (the most often about the features of propaganda) may be replaced with the systematic (permanent) communication and interactive (mutual) communication [Bennett 2003; Lloyd 2009]. The processes on the political market are heading for the same direction as the trade exchange - their considerable part takes place in a virtual world. Key factor of market changes will be participation given by Web 2.0 and social media. The second factor will be e-engaging. During this stage, people can interact with the organization and start a dialogue. The third stage will be e-empowering. This stage is about working together with users, members or citizens. Empowering them with responsibilities, tasks and options to collaborate with the organization.

The hierarchy of public parties - similarly to enterprises - is formed with two or three large and a number of small knots. We have already seen some evidence that e.g. blogs may have direct or indirect effects on political outcomes [Ferber et al. 2003; Drezner and Farrell 2007] as well as various benefits to both citizen consumers and elite users are distinct from traditional news media [Rosen 2007].

\footnotetext{
1 The definition of the term "e-democracy" depends on the political culture of societies and the application scale (locally, nationally or globally). It is likely that nations will learn from each other while developing new practices towards this direction, international comparisons and standardised methods of evaluation [Triantafillou and Kalogeras 2010]. This paper uses the term of "cyberdemocracy" and defines it as citizens' participation in the processes of policy formation, decision making, and implementation through the use of ICT [Shinkai and Naito 2005].
} 
The strategies used by the political subjects in the new digital environment should differ from the ones that are (were) realised in real space only. Their (1) scope, (2) main decisional areas, (3) methods of the allocation of funds and (4) covered tasks are different [Roudavski 2010]. There are four possible forms of relations building (Table 1) between the subjects on the political market; two of them will be popularised in the future.

Table 1. Sellers and receivers of the political products in cyberdemocracy

\begin{tabular}{|c|c|c|c|}
\hline \multicolumn{2}{|c|}{} & \multicolumn{2}{|c|}{ Dealer of the political product } \\
\cline { 3 - 4 } & \multirow{2}{*}{$\begin{array}{c}\text { voter } \\
\begin{array}{c}\text { Customer of } \\
\text { the political } \\
\text { product }\end{array}\end{array}$} & $\begin{array}{c}\text { Traditional space of relations } \\
\text { Political offer created and published } \\
\text { in the same way as it used to be }\end{array}$ & $\begin{array}{c}\text { Coter } \\
\text { Products being the result of the virtual } \\
\text { societies' creation - at the local level, } \\
\text { but with global potential }\end{array}$ \\
\cline { 2 - 4 } & $\begin{array}{c}\text { political } \\
\text { organization }\end{array}$ & $\begin{array}{c}\text { Negotiations and transactions } \\
\text { Political relations between suprana- } \\
\text { tional parties, created among others as } \\
\text { a result of global consolidation }\end{array}$ & $\begin{array}{c}\text { Civil lobbing } \\
\text { Political products being the result of } \\
\text { the civil influence (pressure) on the } \\
\text { authority }\end{array}$ \\
\hline
\end{tabular}

Source: Authors' own study.

As shown in Table 1, not only the traditional broadcaster (grouping, party, trade union, etc.) will be the creator of the political product, but also a single voter or a group of them. It means that creative user in new regime type could co-creates the content. Political market, based on cyberdemocracy environment, connects people when it comes to their political interests, no matter what their status (economic, social, professional) is. The tendency to think about other person (politician) as an equal man is characteristic in that type of environment, especially when the politician is being liked [Gainous and Wagner 2011].

Internet access will support new processes and - if further research can validate this - it means that the possibility of involving ordinary citizens in the process of governance would appear. Unlike mass-media, a network environment allows the electorial influencing, especially at the local level of political communication. The Internet (taking into account the growing trust in its application to commerce) finally provides the opportunity for decision-makers to consider e-voting and social media as a serious challenge for political strategy [Carter and Fielden 2001; Mambrey 2004]. For example, in the year 2007, several dozen people used the environment of the Second Life game to gather (using virtual identities - avatars) in front of the digital symbol of the Capitol, in order to protest against the planned aggression of the USA against Iran. The aim of the Netizens was to draw the attention of the inhabitants to the problem of war and its consequences [Chadwick 2006]. 


\section{Research design and methodology}

The study of political communication, through its various objects and paradigms, appears one of the most active and promising research topics of political science in Poland. The present reports were created based on findings from qualitative survey conducted in Silesia that was a part of a larger research project investigating local political market conditions in Poland. A qualitative research carried out by a depth-interview technique was selected, as the main aim of the research was to uncover politician's and voter's views and experiences.

Primary data were collected from (1) depth-interviews with active local politicians operating in southern Poland, (2) focus group's interview with local NGOs' leaders, (3) an extensive engaged internal observation technique of local political market. Secondary data was obtained from extensive literature research. The aim of this research was to investigate how new channels of political communication influence the social and political behaviour of the members of the political organisation and local leaders localised outside political structures.

Using a broad interview agenda, the respondents were asked to describe their earliest memories of political activity, future plans and demands. Each of the interviews were recorded and transcribed immediately. The data have been analysed line by line to identify codes in each sentence. Depth interviews were focused and through a process of constant comparison politician's responses were grouped into significant categories in order to describe a vision of the political market.

\section{Findings}

The strategic options of the parties within the scope of communication with the target segments of voters are strongly differentiated (Table 2).

Table 2. Strategic options of the parties within the scope of communication with the target segment

\begin{tabular}{|c|c|c|c|c|}
\hline & \multicolumn{3}{|c|}{ Distribution of political contents } \\
\hline & & intensive & selective & exclusive \\
\hline \multirow{4}{*}{$\begin{array}{l}\text { Technique of } \\
\text { communi- } \\
\text { cation of } \\
\text { the political } \\
\text { contents }\end{array}$} & & $\begin{array}{l}\text { Intensive mass } \\
\text { propaganda }\end{array}$ & $\begin{array}{l}\text { Propaganda pressure on the } \\
\text { attractive segment of electors }\end{array}$ & $\begin{array}{l}\text { Hardening of iron } \\
\text { electorate }\end{array}$ \\
\hline & $\begin{array}{l}\text { push mar- } \\
\text { keting }\end{array}$ & $\begin{array}{l}\text { Advertising ban- } \\
\text { ners in mainstream } \\
\text { political portals } \\
\text { and vortals }\end{array}$ & $\begin{array}{l}\text { E-mail and SMS, meaning the } \\
\text { correspondence based on the use } \\
\text { of the defined list of addressees, } \\
\text { creating a segment of receivers }\end{array}$ & $\begin{array}{l}\text { A website where the } \\
\text { access to a certain } \\
\text { content is possible after } \\
\text { authorization }\end{array}$ \\
\hline & & Full information & Building a community & Exclusive contact \\
\hline & $\begin{array}{l}\text { pull market- } \\
\text { ing }\end{array}$ & $\begin{array}{c}\text { Openness } \\
\text { Website available } \\
\text { for every elector } \\
\text { Infoline }\end{array}$ & Social portals & $\begin{array}{l}\text { Internet communicator } \\
\text { enabling blocking the } \\
\text { communication with an } \\
\text { unwanted partner }\end{array}$ \\
\hline
\end{tabular}

Source: Authors' own study. 
The rapid development of technology forces political subjects to change a lot of marketing processes [Finney and Scherrebeck-Hansen 2010]. A choice - that has a vital strategic meaning - is the defining of the need to include to the operated segments those groups of the voters that have not been addressed yet. It is possible to use the multi-criteria segmentation to enable the choice of such actions. Segmentation decisions will make possible to address the content to the chosen group of voters using various digital instruments [O'Leary et al. 2004]. The exemplary matrix of the communication channels to the chosen target groups in a virtual environment (Table 3) contains seven choices.

Table 3. The exemplary matrix of the communication channels to the chosen target groups in a virtual political environment

\begin{tabular}{|c|c|c|c|c|c|}
\hline \multirow{2}{*}{\multicolumn{2}{|c|}{}} & \multicolumn{2}{|c|}{ Key factor influencing the assessment of the parties } \\
\cline { 2 - 6 } & \multicolumn{2}{|c|}{$\begin{array}{c}\text { program decides } \\
\text { predominance } \\
\text { of emotions }\end{array}$} & $\begin{array}{c}\text { predominance } \\
\text { of arguments }\end{array}$ & $\begin{array}{c}\text { predominance } \\
\text { of emotions }\end{array}$ & $\begin{array}{c}\text { predominance } \\
\text { of arguments }\end{array}$ \\
\hline $\begin{array}{c}\text { Voter's } \\
\text { activity in } \\
\text { search for } \\
\text { the political } \\
\text { contents }\end{array}$ & low & $\begin{array}{c}\text { political } \\
\text { blog, v-blog }\end{array}$ & RSS channel & $\begin{array}{c}\text { chat, } \\
\text { discussion forum }\end{array}$ & $\begin{array}{c}\text { party newsletter } \\
\text { corporate website }\end{array}$ \\
\cline { 2 - 6 } & $\begin{array}{c}\text { advertising spots in the social portals, } \\
\text { telemarketing }\end{array}$ & $\begin{array}{c}\text { viral marketing, } \\
\text { computer game }\end{array}$ & $\begin{array}{c}\text { SMS service, } \\
\text { especially the re- } \\
\text { minder about the } \\
\text { date of elections }\end{array}$ \\
\hline
\end{tabular}

Source: Authors' own study.

The selection of the criteria of segmentation is a fundamental strategic choice for the parties, as the consequences of that choice have a long-term character. The segmentation presented above was spread on three criteria simultaneously imposed. Each of them has a subjective character. With the introduction of the criteria, eight segments were separated. The political subject may build long-term market relations with each of target segment. Selecting only one segment (concentrated strategy) makes it possible to meet the expectations of a relatively narrow group of voters, but the subject will be able to become known as a leader in satisfying the needs of the chosen group of voters [Jaśniok 2010]. Another strategic option is a various action directed to several segments and an attempt to meet the needs of each of them with a different marketing offer. The subject should start a relation with each of segment using different communication channels, techniques, marketing tools and instruments [Carlotti et al. 2004].

Some parties may look for such a position in the market that will ensure the best defence against the unfavourable influence of the market conditions, while others would treat unfavourable market environment as a chance to gain an advantage. A new network of relations, new types of relations with voters is a crucial opportunity for the party in cyberspace. It is also worth remembering that - in contrary to the commercial market - the influence of the single political organisation on the sphere of macro environment may be very significant. Political parties create legal conditions, 
i.e. voting system rules, install barriers to entry into the political market, this is why market connections are very complicated, especially when the processes conducted on one market influence the other elements of political market [Keegan 2004].

\section{Conclusion}

There are different visions of future stages of political market: the utopian vision promises that ICT solutions will reinstall Athenian conditions of direct democracy. The dystopian vision announces for the digital future a new information autocracy, a widening digital gap between have and have-nots, the exclusion of large amount of citizens, surveillance and manipulation [Mambrey 2004]. The cyberdemocracy was presented in the article as a new form of the regime type. It was pointed out that the development of the technology of information and communication, as well as the development of the information society create new type of political communication which offers the possibility of inclusion of people discouraged at politics. This situation is an opportunity for the creation of new conditions that will provide specific benefits to citizens. The changes on the market will be very broad and will cover all elements, changing also the network of connections between them. The politicians are becoming party-independent. Simultaneously, voters are becoming not only recipients of messages but they can take the initiative in processes of multidirectional communication.

Unpredictable market conditions force a political party to use the strategic management knowledge, especially facilitating the optimisation of the market entities' decisions, which could be the chance for market survival. There are four crucial data to gather, as a result of strategic analysis: (1) the scenarios of the future and the assessment of the (2) competitive, (3) market and (4) strategic position. That data will enable the choice of optimal methods of action in the future. The deepened segmentation will make possible to match the marketing instruments as well as the specific digital tools to the behavioural profile of a single voter.

This research provides an important perspective of strategic management in the context of political party management. Results of the study indicate the connection between the party's position (competitive, market, strategic) and its key strategic choices. Further to these issues was presented (1) matrix of dealers (sellers) and customers (receivers) of the political products in cyberdemocracy, (2) exemplary simplified matrix of the scenarios of the future, (3) the competitive positions of political subjects according to the geographical range of operation and the communication strategy, (4) the parties' market positions according to their competitive positions and a stage of development of the digital techniques on a given market, (5) the strategic positions of the parties and resulting possibilities of adaptation to the new market conditions, (6) strategic options of the parties within the scope of communication with the target segment together with the most often used digital 
platforms within their limits and (7) the exemplary matrix of the communication channels to the chosen target groups in a virtual environment.

Further development of the political marketing in the new era of cyberdemocracy is desired. Especially, it is highly justified to seek proper relations between a politician and a voter or - broadly speaking - between an authority and citizens. It will be a vital contribution to the theory of knowledge of social sciences.

\section{Bibliography}

Bennett, L., 2003. Communicating Global Activism, "Information, Communication \& Society”, vol. 6, no. 2, 2003, pp. 143-168.

Carlotti, S.J., Coe, M.E., Perrey J., Making Brand Portfolios Work, "McKinsey Quarterly”, 2004 (November), pp. 31-35.

Carter, C., Fielden, K., Towards Cyber-Democracy: True Representation, "The Human Society and the Internet. Internet-Related Socio-Economic Issues. Lecture Notes in Computer Science”, vol. 2105, 2001, pp. 287-288.

Chadwick, A., Internet Politics: States, Citizens, and New Communication Technologies, Oxford University Press, New York 2006, p. 400.

Drezner, D.W., Farrell, H., Introduction: Blogs, Politics and Power: A Special Issue of Public Choice, "Public Choice", vol. 134, no. 1-2, 2008, pp. 1-13.

Ferber, P., Foltz, F., Pugliese, R., The Politics of State Legislature Web Sites: Making E-Government More Participatory, "Bulletin of Science, Technology \& Society", vol. 23, no. 3, 2003 (June), pp. 157-167.

Finney, S., Scherrebeck-Hansen M., Internal Marketing as a Change Management Tool: A Case Study in Re-Branding, "Journal of Marketing Communications", vol. 16, no. 5, 2010, pp. 325-344.

Gainous, J., Wagner, K., Rebooting American Politics. The Internet Revolution, Rowman \& Littlefield Publishers, Inc., New York 2011, p. 222.

Goede, M., Media, Democracy and Governance, [in:] Knowledge Democracy. Consequences for Science, Politics, and Media, R. in 't Veld (ed.), Springer, Berlin-Heidelberg 2010, pp. 114-124.

Jaśniok, M. 2010. Marketing polityczny w środowisku wirtualnym, Katowice 2010, p. 148.

Keegan, W.J., Strategic Marketing Planning: A Twenty-First Century Perspective, "International Marketing Review", vol. 21, no. 1. 2004, pp. 13-16.

Lloyd, J., Keeping Both the Baby and the Bathwater: Scoping a New Model of Political Marketing Communication, "International Review on Public and Non-Profit Marketing", vol. 6, no. 2, 2009, pp. 119-135.

Mambrey, P., Networked ICT to Foster e-Democracy? "Electronic Government. Lecture Notes in Computer Science", vol. 3183, 2004, pp. 31-35.

O’Leary, Ch., Rao, S., Perry, Ch., Improving Customer Relationship Management Through Database/ Internet Marketing. A Theory-Building Action Research Project, "European Journal of Marketing", vol. 38, no. 3-4, 2004, pp. 228-354.

Rosen, Ch., Virtual Friendship and the New Narcissism, "The New Atlantis”, vol. 17, 2007 (summer), pp. 15-31.

Roudavski, S., Virtual Environments as Situated Techno-Social Performances. Virtual West Cambridge Case-Study, the $15^{\text {th }}$ International Conference on Computer Aided Architectural Design Research in Asia, 2010, pp. 477-486.

Shinkai, I., Naito, K., Regional Management and e-Democracy in the Information Society: Communications among Citizens and Officials on the Website Provided by Local Governments for Good Local Management, [in:] Digital Economy and Social Design, O. Sudoh (ed.), Springer, Tokyo 2005, pp. 210-232. 
Tapscott D., Williams A.D., Macrowikinomics. Rebooting Business and the World, Portfolio Penguin, New York 2010, p. 432.

Triantafillou, V., Kalogeras, D., E-Democracy: The Political Culture of Tomorrow's Citizens, [in:] Next Generation Society. Technological and Legal Issues, A.B. Sideridis, C.Z. Patrikakis (eds.), Lecture Notes of the Institute for Computer Sciences, Social Informatics and Telecommunications Engineering, vol. 26, no. 4, 2010, pp. 99-107.

\section{Strategic Marketing of Political Entity in Market Virtualization Context}

The following study is based on the theoretical considerations and qualitative survey to develop hypotheses about the influence of the new regime type-cyberdemocracy - on the management of the political party. This research provides important perspective on the role of strategic management in the context of political parties' behaviour. Results from the study indicate the connection between the party's position (competitive, market and strategic) and its key strategic choices. Using a grounded theory research method, adapted techniques of strategic analysis are proposed. The presented information expands the knowledge about the planning of marketing activities of the parties in the new communication environment.

\section{Strategiczne zarządzanie podmiotem politycznym w kontekście wirtualizacji rynku}

Zawarte w artykule badania zmierzające do weryfikacji hipotez dotyczących wpływy nowego typu ustroju - cyberdemokracji - na zarządzanie podmiotem politycznym oparto na rozważaniach teoretycznych, a także empirycznych badaniach jakościowych. Badania te ukazują istotną perspektywę zarządzania strategicznego w kontekście zachowań partii politycznych. Wyniki naukowych poszukiwań ukazują na związek między pozycją partii (konkurencyjną, rynkową i strategiczną) a jej kluczowymi strategicznymi wyborami. Pozyskane informacje poszerzają wiedzę na temat planowania działań marketingowych podmiotów na rynku politycznym w nowym środowisku komunikacyjnym. 